\title{
Aktivní stárnutí jako idea, nástroj a kapitál. Kde hledat kořeny úspěchu konceptu aktivního stárnutí?
}

\author{
Active Ageing as an Idea, Tool and Form of Capital: \\ What Makes the Concept of Active Ageing So Successful? \\ Jarosla va Hasmanová Marhánková
}

\begin{abstract}
Currently the idea of active ageing represents a perspective that has held a prominent position in gerontology, social work and social policy. It has become a crucial framework for formulating policy related to the issues of population ageing in European countries. This article discusses the factors that helped to establish active ageing as a successful theoretical concept that has significantly influenced current social representations of ageing and continues to have a practical impact on social work and policy. The first part of the article draws upon the work of Murray Davis and her insights into the key aspects that make sociological theory successful. The second part highlights the need to analyse the popularity of the concept of active ageing with respect to the possibilities that such an approach to ageing opens up for social policy, social work and to seniors themselves. It analyses active ageing as a strategy of managing an ageing population, and as a form of professional and individual capital.
\end{abstract}

KEY WORDS Active ageing, population ageing, seniors, social policy

V současné gerontologii a dalších příbuzných vědách tematizujících otázky stárnutí pravděpodobně najdeme jen málo tak vlivných konceptů, jakým je aktivni stárnutí. Spojení „aktivní stárnutí" si vydobylo své pevné místo jako rámec pro široké spektrum témat spojených se životem starší generace (důkazem budiž i název tohoto tematického čísla). Zároveň se stalo významným sloganem zastřešujícím sociální politiku (nejen) stárnoucí Evropy. Česká vláda definovala v Národním programu přípravy na stárnutí na období let 2003 až 2007 aktivní stárnutí jako svou prioritu (v současné verzi dokumentu je termín nahrazen spojením „pozitivní stárnutí", které ale poměrně synonymicky odkazuje na původní pojetí). Podobně i Evropská komise ustavila aktivní stárnutí jako piliřr své sociální politiky ve vztahu ke stárnutí. V roce 2012 pak celá Evropa slavila rok aktivního stárnutí. Podobně významné pozornosti se koncept aktivního stárnutí těši i v sociálních vědách. At’ už se jedná o teoretické studie diskutující jeho různé významy a limity (namátkově Boudiny 2013; Moulaert a Biggs 2012; Walker

Sociální studia. Katedra sociologie FSS MU, 3/2014. S. 13-29. ISSN 1214-813X.

1 Text vznikl za podpory Grantové agentury ČR (grant č. 13-09399P). Veškerou korespondenci zasílejte na adresu: PhDr. Jaroslava Hasmanová Marhánková, Ph.D., Katedra sociologie, Západočeská univerzita v Plzni, Univerzitní 8, 30614 Plzeň. Za podnětné komentáře k první verzi textu děkuji oběma recenzentům/recenzentkám. 
2002, 2008) či empirické studie mapující různé dimenze aktivního stárnutí v životech seniorů a seniorek (napřr. Kuchařová a kol. 2002; Petrová Kafková 2013; Vidovićová 2005).

Kořeny popularity konceptu aktivního stárnutí ${ }^{2}$ sahají do 90 . let minulého století, kdy jej Světová zdravotnická organizace začala poprvé systematičtěji používat v rámci svých politik. Aktivní stárnutí navazuje svým pojetím na podobné koncepce úspěšného (Rowe a Kahn 1997) a později produktivního stárnutí (Bass, Caro a Chen 1993), které se dříve rozvíjely především ve Spojených státech. Od 90. let se pak spojení aktivní stárnutí postupně stává součástí všech významných dokumentů WHO, OECD i Evropské komise tematizujících otázky stárnutí. Samotné definice toho, co aktivní stárnutí znamená, se nicméně (nejen) v těchto textech vyznačují poměrně velkou variabilitou. Zatímco WHO (2002: 12) definuje aktivní stárnutí jako ,proces co nejlepšího využití př́ležitostí pro zdraví, participaci a bezpečnost ke zlepšení kvality života lidí v průběhu stárnutí“, Evropská komise v jednom ze svých dokumentů definuje aktivní stárnutí pouze jako ,přijetí zdravého životního stylu, déle pracovat, odcházet do důchodu později a být aktivním i po tomto ochodu“" (European Commission 1999).

Podobnou různorodost př́stupů k aktivnímu stárnutí nacházíme i v sociálních vědách. Avramov a Mašková (2003: 24) definují aktivní stárnutí jako naplňování „,aktivního života starších lidí v různých oblastech osobního, rodinného, společenského i profesního života“. Specificky pak podle nich aktivní stárnutí odkazuje především k přetrvávající pracovní aktivitě ve stáří, aktivní účasti na rodinném životě (v podobě poskytování pomoci členům rodiny či vykonávání domácích prací), aktivnímu zapojení do života komunity (zvláště ve formě dobrovolnictví) a aktivnímu trávení volného času. Jeden z nejvýznamnějších propagátorů konceptu aktivního stárnutí Alan Walker (2006) ho vnímá jako multidimenzionální strategii, která propojuje individuální i společenskou rovinu. Na společenské úrovni aktivní stárnutí zahrnuje výzvy v oblastech zaměstnání, zdraví, sociální inkluze, vzdělávání či dostupnosti dopravy. Na úrovni jednotlivců mají podle Walkera lidé „,V průběhu celého života povinnost využít celoživotního vzdělávání a prríležitostí ke kontinuálnímu školení a podpoře vlastního zdraví a životní pohody“ (ibid.: 86). Jak je vidět i z předchozí definice, vize aktivního stárnutí je v mnohém vizí normativní, která nabádá ke specifickému životnímu stylu a přístupu ke zdraví. Vychází přitom z předpokladu, že „aktivní životní styl je pozitivně spojený

2 V tomto textu používám spojení „koncept aktivního stárnutí“ a ,idea aktivního stárnutí“ jako synonyma označující specifický způsob uchopování stárnutí, který navazuje na teorii aktivity a rodí se v kontextu diskuzí nad hrozbou demografického stárnutí a potřebou nově redefinovat společenské významy spojené se stárnutím a místem seniorů a seniorek ve společnosti. Klíčovým aspektem konceptu aktivního stárnutí se stávají různé formy aktivity. (V tomto momentě se nejviditelněji vynořuje nejednoznačnost tohoto konceptu, nebot' různé př́stupy definují tuto aktivitu rozdílně. Nejčastěji je však aktivní stárnutí spojováno se zdravým životním stylem a prodlužující se pracovní biografíi.) Tyto různé formy aktivity jsou v rámci konceptu aktivního stárnutí ustavovány jako cesta ke zdravému a spokojenému stárnutí - to znamená, že v sobě obsahuje rovněž specifické pojetí toho, jak vypadá / má vypadat vhodné stárnutí. Tato konceptualizace je silně spjata s aktivním životním stylem a je představována jako univerzálně vhodná pro všechny. Spojením „,politiky aktivního stárnuti'“ označuji formy politických strategií či sociálních programů, které skrze konkrétní opatření usilují o to, převést ideu aktivního stárnutí do praxe. 
s dalšími eticky oceňovanými hodnotami jako osobní autonomie, lepší zdraví, životní spokojenost a kvalita života obecně“ (Avramov a Mašková 2003: 24).

V rekapitulaci dílčích pojetí a definic aktivního stárnutí bychom mohli pokračovat ještě velmi dlouho. ${ }^{3}$ Cílem tohoto textu nicméně není diskutovat různé významy aktivního stárnutí ani limity těchto odlišných prŕstupů. Tento text se zamýšlí nad tím, jak si vysvětlovat popularitu tohoto konceptu a jeho př́buzných variací ve formě pozitivního, úspěšného či zdravého stárnutí v sociálních vědách i v konkrétní sociální politice. Za cíl si tedy klade snahu odpovědět na to, jaké faktory stojí za úspěchem aktivního stárnutí jako teoretického konceptu a formy sociální politiky. V první části textu na koncept aktivního stárnutí nahlížím skrze perspektivu filozofie sociálních věd. Prostřednictvím prací Murray Davis (1986), která se zamýšlí nad kořeny úspěchu klasických sociologických teorií, diskutuji, do jaké míry a jak koncept aktivního stárnutí naplňuje rysy, které podle Davis zaručily těmto teoriím zájem publika a dlouhotrvající oblibu.

Pozornost, které se v současné sociální politice i gerontologii a př́buzných vědách aktivnímu stárnutí dostává, však nelze jednoduše vysvětlit pouze skrze jeho atraktivitu pro široké publikum. Druhá část textu poukazuje na to, že důvody úspěchu aktivního stárnutí je potřeba hledat především v nových možnostech, které tento způsob uvažování nabízí pro sociální politiku, práci se seniory a seniorkami i pro seniory a seniorky samotné. Popularitu a úspěch konceptu aktivního stárnutí přitom analyzuje s ohledem na nové formy kapitálu a možností, které aktivní stárnutí různým aktérům přináší. Na úrovni sociální politiky se aktivní stárnutí stává efektivním způsobem správy stárnoucí populace. V oblasti sociální práce aktivní stárnutí poskytuje novou formu intelektuálního a profesního kapitálu umožňujícího nově definovat a rozšiřovat kompetence gerontologie a institucí věnujících se péči o seniory a seniorky. $\mathrm{Na}$ úrovni jednotlivců se pak aktivní stárnutí stává důležitým zdrojem pozitivních obrazů vlastní identity ve stáŕí i kapitálem, který umožňuje (re)konstruovat původní sociální nerovnosti na pozadí životního stylu. Text analyzuje aktivní stárnutí s ohledem na tyto jednotlivé dimenze a zamýšlí se nad tím, do jaké míry je potřeba úspěch aktivního stárnutí interpretovat právě s ohledem na tyto (často problematické) efekty, které produkuje.

\section{Aktivní stárnutí jako úspěšná sociální teorie}

Jednou z inspirací pro úvahy nad důvody úspěchu konceptu aktivního stárnutí mi byly práce Murray Davis (1986) zaměřující se na identifikování rysů, které spojují úspěšné sociální teorie, jež si vydobyly své místo v kánonu sociálních věd. Davis ve své práci nehodnotí kvalitu těchto teorií ani neusiluje o to, zmapovat kritéria „dobré“ sociální teorie, zamýšlí se ale nad tím, co odlišuje teorie, které si získaly masivní pozornost, od těch, jimž se žádné výrazné pozornosti nedostává. ${ }^{4} \mathrm{~V}$ této části budu následovat tento príklad a pokusím se zmapovat, zda

3 Pro detailnější diskuzi nad těmito otázkami viz např. Boudiny (2013) nebo Hasmanová Marhánková (2013).

4 Druhou inspiraci pro mé úvahy představuje text Kathy Davis (2008), která argumenty své jmenovkyně, jež se zaměřuje především na klasické sociologické teorie Marxe, Webera či Simmela, aplikuje na analýzu úspěšnosti konceptu intersekcionality, který především v genderových studiích 
a př́padně jakým způsobem koncept aktivního stárnutí naplňuje rysy úspěšné teorie, které identifikuje Davis (1986), a tak i odpovědět na to, kde je možné hledat kořeny jeho úspěchu (nejen) v sociálních vědách.

Úspěch sociální teorie je podle Davis (1986) do výrazné míry založen na její lákavosti. Ve své analýze klasických sociálních teorií ukazuje, že všechny tyto kanonické teorie sledují specifickou formu rétoriky. První jejich charakteristikou je, že svou tezi začínají odkazem na něco, co apeluje na zájem publika v celé jeho šíri. Úspěch teorie však podle Davis nespočívá pouze $\mathrm{v}$ identifikování tématu, které je pro lidi zajímavé. Teorie se stává pro široké publikum zajímavá především v momentě, kdy tematizuje úzkost spojenou s ohrožením něčeho, co je publiku drahé a blízké. Takovéto předestření problému poskytuje kontext, kdy se zabývání danou otázkou stává klíčové pro zvládnutí obav veřejnosti. Ukazuje, jak dalekosáhlých změn a významných procesů jsme svědky a jak tyto budou zasahovat do organizace společnosti i individuálních životů lidí. Zároveň úspěšná teorie nabízí naději v podobě možných návrhů, jak se s těmito změnami a procesy vyrovnat nebo se s nimi alespoň naučit žít.

Co je tedy ono drahé a každému blízké, jež koncept aktivního stárnutí uchopuje a jaké obavy zviditelňuje a zároveň pro ně nabízí řešení? Odpověd’ je nasnadě. Koncept aktivního stárnutí tematizuje něco, co je součástí života každého z nás. Dotýká se otázek vyrovnávání se se stárnutím a zachování si důstojnosti a nezávislosti ve stáŕí. Ve svých zjednodušených interpretacích pak nabízí odpovědi na to, jak dospět ke zdravému a spokojenému stárnutí. Koncept aktivního stárnutí se zároveň formuje ruku v ruce s debatami upozorňujícími na rizika demografického stárnutí. Adresuje tak nejen úzkost spojenou se stárnutím individuálním, ale také obavy spojené se stárnutím populace. Druhým dechem zároveň nabízí návody, jak se s oběma těmito procesy vyrovnat. Boom zájmu o aktivní stárnutí vrcholící dnes nejcitovanější definicí od Světové zdravotnické organizace (WHO 2002) je vždy rámován diskuzí nad riziky, které $\mathrm{s}$ sebou nese rostoucí počet seniorů a seniorek ve společnosti. Aktivní stárnutí svou vizí aktivních seniorů, kteří „se kontinuálně zúčastňují sociálního, ekonomického, kulturního, duchovního a veřejného života“ (WHO 2002: 12), „přijímají zdravý životní styl, déle pracují, odcházejí do důchodu později a jsou aktivní i po tomto odchodu“ (European Commission 1999) a v průběhu celého svého života jsou si vědomi ,vlastní odpovědnosti za prípravu na stáří “ (MPSV 2003), představuje politickou reakci na demografické trendy, stejně tak jako odpovědi na otázky po tom, jak by mělo vypadat spokojené a štastné stárí, které se dotýkají každého $\mathrm{z}$ nás.

Dalším rysem, který Davis (1986) zdůrazňuje jako základ úspěchu klasických teorií, je schopnost otevř́it prostor pro specializované bádání i poskytnout snadno zapamatovatelné body a fráze umožňující pochopení i pro ty, kteří se tématu věnují jen okrajově. Úspěšné teorie tak na jednu stranu umožňují specializované akademické bádaní, kdy je možné celou kariéru věnovat pouze detailnímu zkoumání jedné teorie. Na druhou stranu je možné je zjednodušit do snadno uchopitelných a zapamatovatelných spojení či klišé. Koncept aktivního stárnutí naplňuje toto kritérium beze zbytku. V rámci sociálních věd otevírá aktivní stárnutí

představuje jeden z nejvlivnějších přístupů k studiu prolínání sociálních kategorií. Ukazuje tak, že práce Murray Davis má potenciál přinést porozumění úspěchu nejen klasických sociologických teorií, ale i současných vlivných konceptů. 
prostor pro širokou škálu debat. Najdeme studie usilující o to, vyrovnat se s předchozími konceptualizacemi aktivního, zdravého, pozitivního či úspěšného stárnutí (např. Bass a Caro 2001; Moody 2001), které kriticky hodnotí limity předchozích př́istupů a přichází s dalšími a dalšími koncepty (a zároveň tak otevírají dalším badatelům a badatelkám prostor pro reflexi limitů těchto nových prrístupů). Idea aktivního stárnutí se stává výchozím bodem řady empirických výzkumů testujících vztah mezi aktivitou ve stáŕí a životní spojeností či zdravím (např. Nimrod a Adoni 2006; Litwin a Shiovitz-Ezra 2006) či mapující různé dimenze životních stylů seniorů (např. Bútorová et al. 2013; Petrová Kafková 2013). Zároveň se aktivní stárnutí stává zjednodušeným heslem či sloganem, který snadno upoutá pozornost. Spojení aktivní stárnutí evokuje vizi a dynamiku. Je snadno přeložitelné do poutavých frází. V České republice se dnes setkáváme $\mathrm{s}$ tím, že se spojení aktivní stárnutí stává nutným rámcem, ke kterému se musí nějakým způsobem vztáhnout téměř všechny projekty zaměřené na seniory a seniorky. ${ }^{5}$ Koncept aktivního stárnutí tak na jednu stranu otevírá prostor pro detailní akademické bádání. Zároveň ale poskytuje snadno srozumitelné fráze, které jeho popularitu rozšiřují i mimo akademickou sféru. Používání tohoto spojení se přitom často stává až mantrou, která je opakována bez potřeby dalšího vymezení, co je daným pojmem myšleno (ostatně i Národní program př́ípravy na stárnutí na období let 2008 až 2012, který definuje aktivní stárnutí jako svou prioritu, na žádném místě dokumentu neposkytuje definici, co daným termínem vlastně myslí). Není přehnané tvrdit, že odkaz na aktivní stárnutí dnes funguje téměř jako povinná propustka do arény grantových řízení pro projekty zaměřené na starší generace.

Třetím klíčovým rysem, který podle Davis (1986) napomáhá úspěchu sociální teorie, je paradoxně její nejednoznačnost. Mnohoznačnost není podle Davis v sociálních vědách znakem selhání, ale naopak může položit základy budoucí obliby dané teorie. Jak sama poznamenává, „nejednoznačné teorie se mohou obracet na různé - často proti sobě stojící - druhy publika. Dovolují každé podskupině interpretovat teorii vhodným, a přesto neslučitelným způsobem“ (Davis 1986: 296). Úspěšné sociální teorie jsou tedy úspěšné právě proto, že nepřinášejí jasné odpovědi, ale naopak otevírají prostor pro další diskuzi a bádání (Davis 2008). Aktivní stárnutí v mnohém tuto nejednoznačnost zhmotňuje a používá jako svou devízu. Nejen že nenacházíme jednotnou definici významu aktivního stárnutí, shoda nepanuje ani $\mathrm{v}$ tom, zda aktivní stárnutí představuje teorii či př́stup či něco ještě zcela jiného. Aktivní stárnutí je označováno jako proces (WHO 2002), schopnost (OECD 1998: 84), strategie (Walker 2002), koncept (Avramov a Mašková 2003; Ranzijn 2010; Walker 2002), forma sociální politiky (Ney 2005) či diskurzu (Hasmanová Marhánková 2011). Boudiny (2013) dokonce aktivní stárnutí označuje za „vyprázdněnou rétoriku“. I Alan Walker, který se do významné míry zasloužil o etablování tohoto spojení v sociálních vědách, hovoří o tom, že aktivní stárnutí se často stává „sloganem, pod který se může schovat, co je zrovna potřeba“ (Walker 2002: 124). Tuto skutečnost, jak upozorn̆uje Davis (1986), ale není potřeba vnímat

5 Namátkou můžeme zmínit několik významných, nedávno realizovaných projektů zaměřených na seniorskou populaci, jako např. projekty „FRAM - Nový politický rámec pro aktivní, zdravé a důstojné stárnutí“ (http://www.framprojekt.eu/o-projektu [cit. 26. 5. 2014]) či „Aktivní stárnutí jako odpověd' na nadcházející společenskou krizi v České republice a EU“ (http://aktivne.eracr.cz/ [cit. 26. 5. 2014]). 
jako slabinu aktivního stárnutí. Naopak, nejednoznačnost se stává jeho silnou stránkou a klíčem $\mathrm{k}$ jeho nebývalému úspěchu především v rámci sociální politiky. Aktivní stárnutí se stává snadno mobilizovatelným rámcem pro různou škálu sociálních politik. Tajemství úspěchu aktivního stárnutí tak paradoxně leží v tom, že díky své nejednoznačnosti může být překládán podle momentálních potřeb různých jednotlivců i institucí.

Následující část textu se zaměřuje na význam idey aktivního stárnutí v sociální politice, sociální práci a na úrovni vnímání životního stylu a aktivity ve stáŕí. U jednotlivých oblastí se přitom zamýšlí nad významy aktivního stárnutí pro fungování jednotlivých institucí a pozici různých aktérů ve společnosti. Úspěch aktivního stárnutí přitom interpretuje právě s ohledem na efekty, které aktivní stárnutí v těchto jednotlivých dimenzích produkuje.

\section{Aktivní stárnutí jako nástroj spravování stárnoucí populace}

Analýze aktivního stárnutí jako formy biopolitiky, jejímž cílem je kontrola populace skrze životní styly jednotlivců, jsem se již věnovala na jiných místech (Hasmanová Marhánková 2011, 2013: 51-80). Dovolte mi nicméně krátké představení toho, jakým způsobem aktivní stárnutí může fungovat rovněž jako praktický nástroj spravování stárnoucí populace a jakou roli může tato skutečnost sehrávat $\mathrm{v}$ jeho současné oblibě $\mathrm{v}$ rámci sociální politiky.

Geneze konceptu aktivního stárnutí je úzce spjata s diskuzemi nad riziky demografického stárnutí. Úspěšné „tažení“ konceptu aktivního stárnutí v sociální politice (nejen) Evropské unie je úzce spjato s hrozbou zhroucení současného penzijního, sociálního a zdravotnického systému. Aktivní stárnutí je $\mathrm{v}$ těchto debatách vždy silně rámováno potřebou reagovat na významné společenské změny. Jinými slovy, zvyšující se podíl starších lidí v populaci výrazným způsobem mění tvář společnosti. Aktivní stárnutí je prritom situováno do pozice odpovědi na tyto trendy a zároveň klíče $\mathrm{k}$ jejich vyřešení. Politiky aktivního stárnutí zároveň, jak upozorňuje např́ílad Biggs (2001), výrazným způsobem mění rétoriku spojenou s hrozbami demografického stárnutí, které přeznačují na př́iležitosti. Atraktivita aktivního stárnutí je tak dále posilována pozitivní vizí, kterou nabízí. Jak uvádí předmluva Deklarace Evropského roku aktivního stárnutí a solidarity mezi generacemi vydaná Radou Evropské unie (Council of the European Union 2012: 3): „demografické změny mohou být, mimo jiné, úspěšně vyřešeny skrze pozitivní príistup během celého životního cyklu, který se zaměří na potenciál všech generací a zvláště na starší věkové skupiny. Je potřeba umožnit, aby jak ženy, tak muži zůstali aktivními jako zaměstnanci, spotřebitelé, pečovatelé, dobrovolníci a občané a je potřeba podporovat solidaritu mezi generacemi.“

Odpověd' na hrozby demografického stárnutí, kterou aktivní stárnutí nabízí, je tak produkce specifických typů subjektivit „kolonizovaných“ aktivitou a důrazem na produktivitu (Moulaert a Biggs 2012). Spravování stárnoucí společnosti skrze aktivní stárnutí se děje především prostřednictvím disciplinace jednotlivců skrze jejich životní styl. Aktivní stárnutí je představováno jako celoživotní projekt, $\mathrm{v}$ jehož rámci na sobě jednotlivci systematicky pracují směrem k co nejmenší závislosti na sociálním systému a ostatních. ${ }^{6}$ Role státu je v tomto

6 Právě v důrazu na celoživotní charakter projektu aktivního stárnutí je přitom možné spatřovat další pilír jeho úspěchu. Filozofie idey aktivního stárnutí totiž necílí pouze na seniory a seniorky, ale představuje aktivní stárnutí jako výsledek celoživotního snažení. Každý jednotlivec v každé fázi 
ohledu spíše umožñují - tj. jeho úlohou je poskytovat podmínky pro aktivní stárnutí, odpovědnost za jeho individuální naplnění je nicméně situována do rukou konkrétních jednotlivců (srov. Hasmanová Marhánková 2013: 57-62). V současné době tak v České republice můžeme nalézt i Manuál aktivního stárnutí (Manuál 2012) či Bedekr aktivního stárnutí (Holmerová et al. 2013), které se již svými názvy v mnohém stávají zhmotněním procesu produkce aktivně stárnoucích subjektů. Manuál aktivního stárnutí (2012) tak např́íklad na své čtenáŕe/ čtenářky v sekci Aktivní prrístup apeluje podkapitolami s názvy „Hýbejte se“, „Trénujte svůj mozek“, „Bud’te mezi lidmi“. Aktivní př́stup k životu je zároveň představován jako cesta k št’astnému stárnutí, nebot' „aktivní lidé žijí déle, bývají zdravější a spokojenějši““ (ibid.: 47).

Aktivní stárnutí tak na jednu stranu apeluje na jednotlivce, aby byli aktivní s př́slibem zdravějšího a spokojenějš́ího života. Takovýto životní styl se zároveň stává klíčem k odpovědi na výzvy spojené s demografickým stárnutím. Jak uvádí např́klad Národní strategie podporující pozitivní stárnutí pro období let 2012 až 2017 (MPSV 2012: 21): „zlepšování zdravotního stavu obyvatelstva je úzce spojeno s ekonomickým růstem a zvyšováním konkurenceschopnosti“. Spravování populace skrze aktivní stárnutí se tak odehrává především prostřednictvím snahy o vytěžení potenciálu zvyšujícího se počtu seniorů. Zdravější, méně závislí, déle pracující a pomáhající senioři a seniorky symbolizující vizi aktivního stárnutí se $\mathrm{v}$ rámci této rétoriky zároveň stávají klíčem $\mathrm{k}$ vyřešení ekonomických problémů spojených s demografickým stárnutím. Snaha o maximalizaci potenciálu starších lidí se stává leitmotivem politik aktivního stárnutí, která se následně odráží i v konkrétních technikách spravování populace.

Př́kladem může být i index aktivního stárnutí - nový analytický nástroj pro prosazování politik aktivního stárnutí zavedený Evropskou komisí, jehož cílem je „poukázat na nevyužitý potenciál starších lidí co se týče aktivní participace na trhu práce, ve veřejné sférée a nezávislém životě“ (European Commision 2013: 3). Index je konstruován prostřednictvím čtyř základních oblastí. První tři odkazují k individuální dimenzi stárnutí (míra ekonomické aktivity seniorů a seniorek, míra neplacené práce jako dobrovolnická činnost či péče o vnoučata a míra soběstačnosti seniorů a seniorek). Čtvrtá oblast se zaměřuje na společenský kontext (ve smyslu faktorů jako průměrná délka dožití či průměrná výše dosaženého vzdělání v dané zemi). Na základě indexu aktivního stárnutí mohou být porovnáváni jednotlivci (tj. čím vy̌šší index, tím vyšší je míra aktivního stárnutí) i jednotlivé země (Česká republika v roce 2013 zaujímala 11. místo mezi zeměmi EU v žebřičku aktivního stárnutí). Cílem indexu je tak umožnit komparaci a identifikování oblastí, kde země mohou lépe pracovat na aktivním stárnutí svých obyvatel. Zpráva Evropské komise zároveň hovoří o pozitivní korelaci mezi výší indexu aktivního stárnutí a výší HDP, stejně tak jako o existenci pozitivní korelace mezi výší indexu a mírou životní spokojenosti lidí starších 55 let (ibid.: 11). Aktivní stárnutí je tak $\mathrm{v}$ rámci této koncepce představováno jako cesta $\mathrm{k}$ individuálnímu pocitu štěstí, stejně tak jako k ekonomickému blahobytu země.

Výše zmíněný příklad indexu aktivního stárnutí je jen dílčím př́ikladem logiky fungování politik aktivního stárnutí, které stojí za mimořádným úspěchem tohoto konceptu. Aktivní

svého života by měl skrze svůj životní styl a volby pracovat na tom, aby jeho stárnutí bylo aktivní. Disciplinační praktiky spojené s politikami aktivního stárnutí se tak stávají nástrojem spravování celé populace. 
stárnutí je představováno jako pozitivní odpověd' na řadu výzev, kterým (nejenom) současná Evropa bude v souvislosti s demografickým stárnutím čelit. Aktivní stárnutí lze vnímat jako formu governmentality, která dává vzniknout specifickým subjektům aktivně stárnoucích seniorů a seniorek (viz Hasmanová Marhánková 2013; Moulaert a Biggs 2012). Skrze životní styl směřovaný k co největší produktivitě a nezávislosti dochází rovněž k spravování populace, jehož těžiště neleží v zásazích zvnějšku, ale v internalizaci aktivního životního stylu, neustálé péče o zdraví, snahy o co nejdelší pobyt na trhu práce at' již ve formě placené práce či dobrovolnické činnosti jako cesty ke spokojenému stárnutí. Pozitivní etické rámce uvažování o št'astném stárnutí, které jsou v rámci aktivního stárnutí jednotlivcům vštěpovány, jsou zároveň rámovány snahou o vytěžení maximálního (především ekonomického) potenciálu starších lidí. Úspěch konceptu aktivního stárnutí v evropské sociální politice je tak potřeba přičítat (mimo jiné) této elegantní logice spravování populace.

\section{Aktivní stárnutí jako forma profesního kapitálu}

Narativum spojující aktivitu s cestou ke spokojenému a zdravému stárnutí sehrálo rovněž významnou roli v rozširrení pole působení gerontologie a upevnění pozice sociální práce ve vztahu k seniorům (Green 2009; Katz 2000). Toto narativum nabídlo aktivitu jako důležitý intelektuální a profesní kapitál. Nejasnost samotného významu „aktivita“ a jejích definičních rámců umožňuje gerontologii sehrávat důležitou úlohu v procesu vymezování toho, jak vypadá ona žádoucí aktivita ve stáŕí a co vůbec za aktivitu můžeme považovat. Nacházíme tak řadu pokusů o vymezení různých podob stárnutí skrze aktivity, kterých je člověk schopen (např. škála ADL - activity of daily living - používající se k definici různých stupňů [ne]závislosti člověka ve stáŕí), či skrze aktivity, které preferuje. Lidé tak mohou být na základě svých aktivit rozlišováni do skupin (ne)produktivně, (ne)úspěšně či (ne)aktivně stárnoucích. Kuchařová a kol. (2002) tak např́klad ve své studii rozdělují české seniory a seniorky na základě činností, jimž se věnují, do čtyř skupin - „mnohostranný, spíše intelektuálský“،, „manuálně orientovaný“, ,intelektuálský, orientovaný na pomoc druhým“ a na „pasivní“. Podobně jako další studie (srov. např. Nimrod a Adoni 2006) pak spojují charakter životního stylu definovaný skrze tyto aktivity s mírou pocitů osamělosti, životní spokojenosti či závislosti. Jakkoliv výše zmiňované studie shodně spojují charakter aktivity ve stáří s podobou předchozí životní biografie a především sociodemografickými charakteristikami jednotlivců, jako jsou vzdělání, gender či výše předchozího př́ijmu, životní styl (definovaný skrze vykonávané aktivity) je zde prezentován jako faktor ovlivňující míru spokojenosti ve stáří. Aktivita se tak v dominantním gerontologickém diskurzu stává nezpochybňovanou cestou ke št’astnému stárnutí a osou reprezentací vymezující rozdíl mezi „dobrým“ a „méně dobrým“ stárnutím. Získává tak rovněž etický rozměr v možnosti přiřazovat různá kladná či záporná znaménka různým podobám stárnutí (často bez hlubší reflexe nad tím, do jaké míry mohou skutečně všichni lidé vizi aktivity dostát). Možnost definovat, co je za onu ,vhodnou“ aktivitu považováno, a zároveň zprostředkovávat cestu k ní, se pak stává důležitým profesním kapitálem gerontologie a především jednotlivých institucí a aktérů v oblasti práce se seniory.

Teorie aktivity, ze kterých koncept aktivního stárnutí vychází, nabízí nejen teoretický rámec pro uvažování o stárnutí a jeho dopadech na jednotlivce, ale rovněž „návody“ zvládání 
stárnutí, které se staly optimistickou odpovědí na dřívější teorie stárnutí popisující stáŕí jako období bez společenské role charakteristické odklonem od dřívějších činností, aktivit i vztahů. Spojení mezi životním stylem, aktivitou a spokojeným stáŕím přineslo nový etický rámec do uvažování o stárnutí, kde aktivita získává nádech univerzálního „dobra“ (srov. Katz 2000: 139). Diskurzy vycházející z teorie aktivity zároveň dovolily gerontologii rozšírít pole působnosti (Green 2009). Aktivní stárnutí nenabízí pouze etické rámce uvažování o stárnutí, ale stává se i rezervoárem konkrétních návodů, jak tuto pozitivní vizi naplnit. „Spravování“, „ř́zení“ a „zprostředkovávání“ aktivity se stalo expertním kapitálem (srov. rovněž Katz 1996a, 1996b, 2000), a tak i jedním z nejvýznamnějších rámců, na který se odvolávají instituce a aktéŕi poskytující sociální služby pro seniory při vymezení své role a významu. Například Zákon o sociálních službách (108/2006 Sb.) uvádí proces aktivizace jako základní součást působení všech institucí poskytujících služby seniorům. „Posilování životní aktivizace“ je v tomto zákoně ukotveno jako jeden z klíčových rysů definice náplně práce sociálního pracovníka (ibid.: § 116). Aktivita se v rámci tohoto prŕstupu stává měřitelným (a vykazovatelným) aspektem a zároveň nástrojem spojujícím profesní expertizy s každodenním životem seniorů a seniorek. Diskurzy aktivního stárnutí tak v tomto ohledu sehrávají důležitou roli i v procesu budování profesní identity sociálních služeb a náplní programů institucí zaměřených na seniory. Samotný koncept aktivizace přitom implicitně přikládá aktérskou roli především sociálním pracovníkům, kteří jsou těmi, kdo aktivizují, zatímco klienti a klientky jsou aktivizováni. Jak uvádí například česká příručka věnující se aktivizačním př́ístupům k osobám seniorského věku: „fenomén aktivita seniorů lze chápat jako jistý výsledný produkt aktivizace seniorư“ (Müller 2006: 37). Aktivita je v této perspektivě představována především jako výsledek činnosti sociálních pracovníků a specializovaných institucí. Zmíněná citace zároveň ilustruje roli expertizy v procesu definování toho, co je aktivitou. V tomto př́padě je jako aktivita označeno především to, co je výsledkem působení specialistů.

Role aktivity jako profesního kapitálu v rámci sociálních služeb zároveň dobře ilustruje ambivalentnost konceptu aktivního stárnutí a jeho otevřenost $\mathrm{k}$ různým překladům. Zatímco $\mathrm{v}$ rámci politik aktivního stárnutí prosazovaných na úrovni mezinárodních organizací a národních strategií je aktivní stárnutí prezentováno jako individuální celoživotní reflexivní projekt, kdy (především) jednotlivci přebírají odpovědnost za své stárnutí prostřednictvím svého životního stylu, prístupy dominující v rámci sociální práce se seniory a seniorkami představují aktivitu jako nástroj, který je v rukou (především) profesionálů. ${ }^{7}$ Diskurzy spojující aktivitu s žádoucí vizí podoby života ve stáŕí se tak zároveň stávají důležitým kapitálem pro ty, již jsou v praxi situováni do role nositelů cest $\mathrm{k}$ „,správné“ aktivitě.

\section{Aktivita jako nová forma individuálního kapitálu}

Představa aktivního stárnutí sehrává výraznou roli v nabourávání tradičních ageistických stereotypů spojujících stárí s obdobím pasivity a pesimismu. Jak poukazuje Biggs (2001), tyto politiky se zdají být na první pohled nápomocné, nebot' přeznačují významy stárnutí

Za upozornění na tento paradox v př́stupu různých aktérů k odpovědnosti za aktivitu děkuji recenzentovi/recenzentce tohoto textu. 
a zdůrazňují především potenciál starších lidí. Aktivity spojené s produktivním věkem (a především ty spojené $\mathrm{s}$ trhem práce) jsou $\mathrm{v}$ rámci těchto narativ představovány jako terapie pro stárnoucí společnost a zároveň prostředek inkluze seniorů. ${ }^{8}$ Tyto aktivity vystupují jako záchranný kruh a nabízí nové zdroje budování identity založené na pozitivních obrazech stárnutí. Biggs ale zároveň varuje před tím, že tato forma inkluze má své omezené rámce. Některé aktivity (jako např́klad pečovatelství či jen pouhý odpočinek) z představ o správném naplnění potenciálu starších lidí vypadávají, podobně jako ne všichni mohou či chtějí jít cestou životního stylu, který v mnohém kopíruje aktivity produktivního věku. Dyk et al. (2013) v této souvislosti varují před tendencí homogenizovat starší lidi, která je součástí politik aktivního stárnutí. Tyto politiky zdůrazňují, že každý senior a každá seniorka jsou nositeli potenciálu, který jen čeká na objevení a následně umožní jejich aktivnější zapojení do společnosti. Druhým dechem tak zároveň produkuje nové normy stárnutí - vizi určitého životního stylu, vůči kterému jsou senioři a seniorky poměřováni. Tyto diskurzy tak zároveň produkují obrazy aktivně stárnoucích seniorů, kteří svým životním stylem naplňují pozitivní vizi stárnutí naplněného aktivitou, a zaslouží si tak náš obdiv, a které fungují jako modely, vůči nimž jsou ostatní poměřováni (a řada z seniorů a seniorek nutně při tomto srovnání selhává).

Zároveň koncepce aktivního stárnutí pracují s představou jednotlivců, kteří skrze své životní styly a individuální volby přebírají odpovědnost za kvalitu svého života ve stáří (srov. Hasmanová Marhánková 2013; Cardona 2008; Jolanki 2008; Neilson 2006). Aktivní stárnutí je v rámci těchto definic představováno jako výsledek odpovědného a uvážlivého životního stylu ve všech fázích života. WHO (2002: 17) například ve svém klíčovém dokumentu hovoří o tom, že „individua a rodiny musí plánovat a přemýšlet o stárnutí a každý musí usilovat o prrijmutí pozitivních, zdraví prospěšných praktik v každé fázi života“. Aktivní stárnutí je tak představováno jako nikdy nekončící úsilí odpovědně pracovat na svém zdravém životním stylu. Podobně i Evropská komise začíná svou definici aktivního stárnutí v praxi odkazem na „přijetí zdravého životního stylu“ (European Commission 1999).

Jak je vidět i z předchozích definic aktivního stárnutí, koncept životního stylu je neproblematicky užíván jako hlavní prostředek dosažení zdravého stárnutí. Zjednodušující politiky aktivního stárnutí prìtom se zdravým životním stylem pracují jako s výsledkem individuálního snažení a správných voleb. Takovéto pojetí snadno vede $\mathrm{k}$ stigmatizaci těch, kteří tyto volby nečiní a vhodný životní styl nereprezentují. Řada předchozích studií v této souvislosti upozorňuje na to, že senioři samotní používají důraz na svůj aktivní životní styl jako prostředek vymezení se vůči negativním obrazům stárnutí i vůči svým vrstevníkům (Hurd 1999; Lund

$8 \quad \mathrm{~V}$ rámci zjednodušeného pojetí aktivního stárnutí, symbolizovaného např́iklad konceptualizací Evropské komise, tyto aktivity zahrnují především pokračující ekonomickou aktivitu a celoživotní vzdělávání. V širších pojetích se prostředkem inkluze stávají aktivity odkazující na hodnoty produktivity. Zdůrazňovány jsou především aktivity, které sledují logiku pracovního života a které přispívají k celospolečenskému blahu (jako jsou napřs. pomoc v rodině a dobrovolnická činnost) či vyzdvihují potřebu neustálého zaneprázdnění (a ne odpočinku evokujícího neproduktivitu), jako je tomu v př́ípadě důrazu na aktivně trávený volný čas (srov. rovněž Avramov a Mašková 2003: 24). Jak poukazuje Ekerdt (1986), tato „etika zaneprázdněnosti“ (busy ethic) napomáhá legitimizovat instituci důchodu ve společnostech, kde práce a produktivita nesou vysokou hodnotu. 
a Engelsrud 2008; Townsend, Godfrey a Denby 2006; Sýkorová 2007). Aktivní životní styl se tak stává významným zdrojem vlastního sebevědomí. Jak ale ukazuji i ve svém předchozím výzkumu, toto pozitivní sebehodnocení se zároveň stává podkladem pro vytváření nových „hierarchií“ podob stárnutí, ke kterým se senioři a seniorky často vztahují. Aktivní životní styl ve stáŕí v tomto ohledu působí nejen jako zdroj sebevědomí, ale rovněž jako prostředek budování vlastní pozice ve vztahu k jiným životním stylům ve stárí (Hasmanová Marhánková 2010).

Jak se pokusím ukázat $\mathrm{v}$ následující části, tyto diskurzy, které individualizují odpovědnost za vlastní stárnutí a zároveň spojují toto odpovědné (a štastné) stárnutí s určitými podobami životního stylu, dávají vzniknout rovněž novým formám „kapitálu“, jež se stává zdrojem (staro)nových nerovností ve stáří. Jak upozorňuje např́iklad Katz (2013: odstavec 5), životní styl je potřeba chápat především jako výsledek tř́́dního postavení, které je vyjadřováno symbolicky i specifickým typem chování a nese s sebou i morální konotace. Reprezentování specifické formy životního stylu a aktivity, jež je v rámci diskurzu aktivního stárnutí rozpoznatelná jako hodnotná, se tak stává i formou kapitálu, na jehož podkladě mohou být rekonstruovány některé z původních nerovností, které vstup do důchodu může potenciálně zneviditelňovat.

Odchod do důchodu, který v současnosti představuje jeden ze symbolických mezníků vnímání stárnutí, představuje tranzici, která výrazným způsobem přeznačuje původní sociální statusy a s nimi spojené různé pozice $\mathrm{v}$ rámci společenské struktury. Důchodem jednotlivec vstupuje do prostoru „statusové rozporuplnosti“ (Formosa 2007: 11). Předchozí identity a postavení odvíjející se od pozice v rámci pracovního trhu ze dne na den mizí. Pokles př́jmu spojený se vstupem do důchodu vede u starších věkových skupin $\mathrm{k}$ př́ijmové nivelizaci a situuje seniory do pozice těch, již jsou závislí na pomoci státu (Townsend 1981). V prostředí kladoucím důraz na produktivitu a nezávislost ztrácí jednotlivci, kteří nereprezentují tyto hodnoty, společenskou prestiž a uznání. Status důchodce se stává dominantním statusem, který má schopnost zneviditelnit předchozí heterogenitu identit a společenských postavení. Formosa (2007: 11) v této souvislosti poznamenává, že není překvapením, že střední a vyšší tř́́dy usilují o to, vstupovat do nových arén, které by jim umožnily znovu ustavit jejich původní společenské postavení. Životní styl se v situaci mizejících struktur trhu práce a postupné ztráty původních společenských rolí a statusů stává důležitým prostředkem budování vlastní identity i vytváření nových forem hierarchií.

Jakkoliv politiky aktivního stárnutí favorizují především představu aktivního/zdravého životního stylu jako výsledku individuálního odpovědného snažení, životní styl je potřeba chápat především jako produkt zvnitřnělé společenské struktury. Bourdieu (1984) v této souvislosti hovoří o životním stylu jako o produktu habitu, který strukturuje dispozice k určitému jednání či porozumění světu kolem nás. Tyto dispozice vedou jednotlivce $\mathrm{k}$ tomu, jednat a vztahovat se k okolnímu světu určitým způsobem. Habitus představuje zvnitřnělou společenskou pozici, která se vpisuje do těl jednotlivců a projevuje se prostřednictvím specifických vkusů. Zároveň se stává prostředkem ustavování společenských nerovností skrze životní styly, jež tyto vkusy produkují. Ne každý vkus a ne každý životní styl je hodnocen jako stejně hodnotný či „kulturní“. Dominance vyšších tříd nad nižšími je v Bourdieově pojetí v současné společnosti manifestována ani ne tak skrze materiální prostředky jako prostřednictvím hierarchií „lepších“ a „horších“ vkusů. 
Řada autorů a autorek upozorňuje na to, že rysy spojované s aktivním stárnutím (jako jsou prodloužená pracovní aktivita, celoživotní vzdělávání, aktivní zdravý životní styl...) jsou součástí životního stylu především střední tř́́dy a že i obrazy aktivních seniorů, které jsou $\mathrm{v}$ rámci těchto diskurzů předkládány jako vhodný model stárnutí, symbolicky referují především k životnímu stylu určité sociální skupiny (Calasanti, Slevin a King 2006; Hendricks a Hatch 2006). Ačkoliv nejcitovanější pojetí aktivního stárnutí z pera WHO (2002) jej pojímá jako komplexní proces odkazující na různé roviny zlepšení života seniorů, v praxi je tento pojem překládán do mnohem užších definic. Jak uvádí již zmiňovaná definice Evropské komise, v praxi aktivní stárnutí znamená především „přijetí zdravého životního stylu, déle pracovat, odcházet do důchodu později a být aktivním i po tomto odchodu“ (European Commission 1999). Jednotlivé aspekty aktivního stárnutí jsou tak úzce svazovány především s participací na trhu práce a zdravým životním stylem (vedoucím k co nejmenší závislosti seniorů na státu).

Podobnou tendenci můžeme vidět i v pojetí politik aktivního (či pozitivního) stárnutí v České republice. Národní akční plán podporující pozitivní stárnutí pro období let 2013 až 2017 definuje jako své priority: zajištění a ochranu lidských práv starších osob (myšleno především jako odstraňování věkové diskriminace), celoživotní učení, zaměstnávání starších pracovníků, dobrovolnictví a mezigenerační spolupráci, zajištění kvalitního prostředí pro život seniorů (odkazující především $\mathrm{k}$ bytové politice a dopravní obslužnosti) a zdravé stárnutí (myšleno podpora zdravého životního stylu, nebot' „zdraví je zásadním předpokladem pro aktivní začlenění na trh práce, do společenských i dobrovolnických aktivit“ [MPSV 2012: 36]). Aktivity, které tento dokument představuje jako součást pozitivního stárnutí, tak odkazují především k pracovní aktivitě, kontinuálnímu vzdělávání se, zapojení se do veřejného života a aktivnímu zdravému životnímu stylu.

Je přitom na místě se zamýšlet, do jaké míry se jedná o aktivity, které symbolizují hodnoty především střední tř́ídy, která se stává také jejich nositelem mezi seniory. Jsou to právě lidé s vyšším vzděláním, kteří naplňují vizi aktivního stárnutí a setrvávají na trhu práce co nejdéle. ${ }^{9}$ Důvodem je pravděpodobně i charakter zaměstnání, jež tito lidé zastávají, který umožňuje jednak jeho vykonávání do pozdějšího věku a zároveň potenciálně poskytuje větší míru seberealizace. Jak ukazuje i výzkum Vidovićové (2008), lidé s vysokoškolským vzděláním častěji hodnotí odchod do důchodu jako nepř́ijemný zážitek, zatímco kvalifikovaní dělníci patřili mezi skupinu, která o důchodu nejčastěji hovořila jako o radostné události. Je to tak do výrazné míry především struktura trhu práce a odlišný charakter jednotlivých povolání, jež různé socioekonomické a vzdělanostní skupiny vykonávají, které se promítají do zapojení na trhu práce $\mathrm{v}$ pozdějším věku. Podobně i zapojení se do celoživotního vzdělávání je především aktivitou lidí, kteří již nositeli vyššího vzdělání jsou (Rabušic 2008).

I zdravý životní styl, který je nejčastěji spojován s individuálním úsilím, je potřeba vnímat jako produkt specifického postavení v rámci sociální struktury. Jak poznamenává

9 Vzdělání představuje jednu z nejvýraznějších determinant participace na trhu práce v pozdějším věku. Např́klad mezi ekonomicky aktivními seniory a seniorkami pobírajícími starobní důchod tvoří lidé s maturitou a vyšším vzděláním 64 \% zastoupených, ačkoliv jsou v této populaci zastoupeni jen z 38 \% (ČSÚ 2012). 
Bourdieu (1984: 213-214), důraz na kultivaci těla a kult zdraví je součástí habitu především střední třídy, která díky svému ekonomickému kapitálu získává lepší príistup ke kvalitnější zdravotní péči a zároveň je nositelkou dostatečného kulturního kapitálu, aby se dokázala orientovat ve vědění o tom, jak na svém zdraví nejlépe pracovat. ${ }^{10}$ Katz (2013: odstavec 7) v této souvislosti upozorňuje, že habitus představuje rovněž „internalizaci omezení transformovaných do individuálních dispozic ke zdravým volbám“. Není pak překvapením, že vyšší a bohatší vrstvy s nejsnazším přístupem k výhodám a službám zdravotní péče jsou také těmi, kdo je nejlépe schopen propojit své volby s životním stylem, který produkuje ve vztahu ke zdraví pozitivní výsledky. Glorifikace určitého životního stylu, voleb a aktivit jako vhodnějších nutně zvýhodňuje ty, již ve svém habitu nesou dispozici $\mathrm{k}$ tomuto typu jednání. Diskurzy aktivního stárnutí, které ustavují určité životní styly jako vhodnější model stárnutí a zároveň je představují jako výsledek individuálních voleb, tak zároveň poskytují prostor pro legitimizaci původních třídních hierarchií. Životní styl ve stáŕí se tak díky diskurzům aktivního stárnutí stává významným kapitálem, který umožňuje (re)konstruovat původní sociální nerovnosti na pozadí schopnosti naplnit vizi aktivního stárnutí spojovanou se specifickými formami aktivity.

\section{Závěr}

Spojení aktivní (či zdravé, pozitivní nebo úspěšné) stárnutí dnes tvoří významnou osu vztahování se k politikám stárnutí i představám o vhodných podobách individuálního života ve stáří. Jak poznamenává Walker (2008), aktivní stárnutí se dnes stává vůdčí globální strategií v odpovědi na populační stárnutí. V tomto ohledu je namístě se ptát, co stojí za úspěchem tohoto konceptu a čemu aktivní stárnutí vděčí za své současné vůdčí postavení. Tento text se pokusil nastínit některé z možných odpovědí na tyto otázky. Ve své analýze se přitom nezaměřoval na hodnocení „kvality“ tohoto konceptu či míry propracovanosti jeho dílčích tezí. Na aktivní stárnutí nahlížel s ohledem na efekty, které takovéto přemýšlení o stárnutí produkuje. Domnívám se přitom, že kořeny úspěchu aktivního stárnutí je potřeba hledat nejen v logice jeho argumentů, ale především v dopadech, které má na fungování sociální politiky, sociální práci se seniory i na vnímání a prožívaní života ve stárí.

Tento text představuje aktivní stárnutí nejen jako koncept usilující o uchopení zkušenosti stárnutí, ale rovněž jako formu diskurzu poskytující různé nástroje a nové formy kapitálu různým aktérům. Je přitom potřeba upozornit, že ne všichni jsou schopni z těchto nových forem kapitálu profitovat stejným způsobem, stejně tak jako disciplinační mechanismy, které se stávají základem politik aktivního stárnutí, dopadají odlišně na různé aktéry. Jak jsem se nicméně pokusila nastínit výše, i v těchto problematických aspektech spojených s konceptem aktivního stárnutí je potřeba hledat kořeny jeho současného úspěchu. Cílem tohoto textu přitom není vyvolat dojem, že se jedná o úspěch neoprávněný. Koncept aktivního

10 Tuto skutečnost Národní akční plán podporující pozitivní stárnutí pro období let 2013 až 2017 částečně reflektuje, když hovoří o tom, že „zvláštní důraz musí být kladen na osoby s nízkým socioekonomickým statusem a na národnostní a etnické menšiny“, a zdůrazňuje potřebu reflektovat odlišné potřeby vyvěrající z heterogenity seniorské populace (MPSV 2012: 37). 
stárnutí bezesporu přináší zásadní a především vítanou změnu do způsobů, jakými bylo tradičně o stárnutí a roli seniorů a seniorek ve společnosti uvažováno. Řada z problematických aspektů, na které tento text upozorňuje, nevyvěrá ze samotné idey aktivního stárnutí tak, jak ji např́klad definuje WHO (2002), ale spíše z různých překladů tohoto konceptu. Jak jsem se snažila naznačit výše, mnohoznačnost konceptu aktivního stárnutí je jedním z kličů $\mathrm{k}$ jeho úspěchu. Jeho otevřenost různým, často protichůdným výkladům však bohužel často vede k některým nezamýšleným efektům. Tyto efekty paradoxně privilegované postavení aktivního stárnutí $\mathrm{v}$ různých sférách společnosti spiše posilují. A je to právě skutečnost, že různé překlady aktivního stárnutí mohou být využívány různými aktéry a institucemi k různým účelům, jež je potřeba vnímat jako základ jeho nebývalého úspěchu. Tato skutečnost by nás nicméně neměla vést $\mathrm{k}$ tomu koncept aktivního stárnutí zavrhnout. Měla by nás ale nabádat k větší citlivosti k tomu, jak je tato idea překládána, s jakými cíly a s jakými dopady.

\section{Literatura}

AVRAMOV, Dragana a Miroslava MAŠKOVÁ. Active ageing in Europe. Strasbourg: Council of Europe Publishing, 2003. ISBN 978-92-871-5240-4.

BASS, Scott A., Francis G. CARO a Yung-Ping CHEN. Achieving a Productive Aging Society. Westport: Praeger, 1993. ISBN 0-8656-9032-4.

BASS, Scott A. a Francis G. CARO. Productive aging. A conceptual framework. In MORROW-HOWELL, Nancy, James HINTERLONG a Michael SHERRADEN (eds.). Productive Aging. Concepts and Challenges. Baltimore: The Johns Hopkins University Press, 2001, s. 37-81. ISBN 0-8018-6557-3.

BIGGS, Simon. Towards critical narrativity. Stories of aging in contemporary social policy. Journal of Aging Studies, 2001, roč. 15, č. 4, s. 303-316. ISSN 0890-4065.

BOUDINY, Kim. "Active ageing": from empty rhetoric to effective policy tool. Ageing \& Society, 2013, roč. 33, č. 6, s. 1077-1098. ISSN 0144-686X.

BOURDIEU, Pierre. Distinction: A Social Critique of the Judgement of Taste. Cambridge (MA): Harvard University Press, 1984. ISBN 978-0674212770.

BÚTOROVÁ, Zora a kol. Štvrtý rozmer tretieho veku. Desat kapitol o aktívnom starnutí. Bratislava: Inštitút pre verejné otázky, 2013. ISBN 978-80-89345-44-1.

CALASANTI, Toni M., Kathleen F. SLEVIN a Neal KING. Ageism and Feminism: From "Et Cetera" to Centre. NWSA Journal, 2006, roč. 18, č. 1, s. 13-30. ISSN 1040-0656.

CARDONA, Beatriz. "Healthy ageing" policies and anti-ageing ideologies and practices: on the exercise of responsibility. Medical Health Care and Philosophy, roč. 11, č. 4, s. 475-483. ISSN 1386-7423.

COUNCIL OF THE EUROPEAN UNION. Council Declaration on the European Year for Active Ageing and Solidarity between Generations (2012): The Way Forward [online]. Council of the European Union, (C) 2012 [cit. 25. 5. 2014]. Dostupné z: http://www.foragenetwork.eu/en/database/item/ 153-2012-council-declaration-on-the-european-year-for-active-ageing-and-solidarity-between-generations-the-way-forward/.

ČSÚ. Důchodci a jejich aktivita na trhu práce [online]. Praha: Český statistický úr̆ad, (C) 2012 [cit. 4. 8. 2014]. Dostupné z: http://www.czso.cz/csu/csu.nsf/ainformace/77D200489915.

DAVIS, Kathy. Intersectionality as buzzword: A sociology of science perspective on what makes a feminist theory successful. Feminist Theory, 2008, roč. 9, č. 1, s. 67-85. ISSN 1464-7001. 
DAVIS, Murray S. „That's Classic!” The Phenomenology and Rhetoric of Successful Social Theories. Philosophy of the Social Sciences, 1986, roč. 16, č. 3, s. 285-301. ISSN 1552-7441.

DYK, Silke van, Stephan LESSENICH, Tina DENNINGER a Anna RICHTER. The Many Meanings of "Active Ageing”. Confronting Public Discourse with Older People's Stories. Recherches sociologiques et anthropologiques, 2013, roč. 44, č. 1, s. 97-115. ISSN 2033-7485.

EKERDT, David J. The Busy Ethic: Moral Continuity Between Work and Retirement. The Gerontologist, 1986, roč. 26, č. 3, s. 239-244. ISSN 0016-9013.

EUROPEAN COMMISSION. New Paradigms in Ageing Societies [online]. European Commission, (C) 1999 [cit. 25. 5. 2014]. Dostupné z: http://ec.europa.eu/employment_social/soc-prot/ageing/ news/paradigm_en.htm.

EUROPEAN COMMISSION. Policy Brief: Introducing the Active Ageing Index [online]. European Commision, (C) 2013 [cit. 25. 5. 2014]. Dostupné z: http://www.foragenetwork.eu/en/database/item/ 152-2013-introducing-the-active-ageing-index-policy-brief/.

EVROPSKÁ ROZVOJOVÁ AGENTURA. Manuál aktivního stárnutí [online]. Praha: Evropská rozvojová agentura, (C) 2012 [cit. 25. 5. 2014]. Dostupné z: http://aktivne.eracr.cz/wp-content/uploads/2013/ 01/A5-manual_nahled.pdf.

FORMOSA, Marvin. A Bourdieusian interpretation of the University of the Third Age in Malta. Journal of Maltese Education Research, 2007, roč. 4, č. 2, s. 1-16. ISSN 1726-9725.

GREEN, Brian. Gerontology and the Construction of Old Age. New Brunswick: Aldine Transaction, 2009. ISBN 978-0202362557.

HASMANOVÁ MARHÁNKOVÁ, Jaroslava. Konstruování představ aktivního stárnutí v centrech pro seniory. Sociologický časopis, 2010, roč. 46, č. 2, s. 211-234. ISSN 0038-0288.

HASMANOVÁ MARHÁNKOVÁ, Jaroslava. Leisure in old age - disciplinary practices surrounding the discourse of active ageing. International Journal of Ageing and Later Life, 2011, roč. 6, č. 1, s. 5-32. ISSN 1652-8670.

HASMANOVÁ MARHÁNKOVÁ, Jaroslava, Aktivita jako projekt. Diskurz aktivního stárnutí a jeho odezvy v životech českých seniorů a seniorek. Praha: Sociologické nakladatelství, 2013. ISBN 9788074191527.

HENDRICKS, Jon a Laurie RUSSELL HATCH. Lifestyle and Aging. In BINSTOCK, Robert H. a Linka K. GEORGE (eds.). Handbook of Aging and the Social Science. 6th ed. London: Academic Press, 2006, s. 301-320. ISBN 978-0-12-088388-2.

HOLMEROVÁ, Iva, Olga STAROSTOVÁ, Radka VEPŘKOVÁ a Petr WIJA. Bedekr aktivního stárnutí. Praha: Fakulta humanitních studií Univerzity Karlovy [online]. 2013 [cit. 25. 5. 2014]. Dostupné z: http:/www.cello-ilc.cz/wp-content/uploads/2013/11/bedekr.pdf.

HURD, Laura C. "We're Not Old!": Older Women's Negotiation of Aging and Oldness. Journal of Ageing Studies, 1999, roč. 13, č. 4, s. 419-439. ISSN 0890-4065.

JOLANKI, Outi. Discussing responsibility and ways of influencing health. International Journal of Ageing and Later Life, 2008, roč. 3, č. 1, s. 45-76. ISSN 1652-8670.

KATZ, Stephen. Busy Bodies: Activity, Ageing and the Management of the Everyday Life. Journal of Ageing Studies, 1996a, roč. 14, č. 2, s. 135-152. ISSN 0890-4065.

KATZ, Stephen. Disciplining old age. The formation of gerontological knowledge. London: University Press of Virginia, 1996b. ISBN 978-0813916613.

KATZ, Stephen. Active and Successful Aging. Lifestyle as a Gerontological Idea. Recherches sociologiques et anthropologiques, 2013, roč. 44, č. 1, s. 33-49. ISSN 2033-7485.

KUCHAŘOVÁ, Věra, Ladislav RABUŠIC a Lucie EHRENBERGEROVÁ. Život ve stáři. Zpráva z empirického výzkumu. Praha: VÚPSV, Socioklub, 2002.

LITWIN, Howard a Sharon SHIOVITZ-EZRA. The association between activity and well-being in later life: what really matters? Ageing \& Society, 2006, roč. 26, č. 2, s. 225-242. ISSN 0144-686X. 
LUND, Anne a Gunn EENGELSRUD. "I am not that old": inter-personal experiences of thriving and threads at a senior centre. Ageing \& Society, 2008, roč. 28, č. 5, s. 675-692. ISSN 0144-686X.

MOODY, Harry R. Productive Aging and the Ideology of Old Age. In MORROW-HOWELL, Nancy, James HINTERLONG a Michael W. SHERRADEN (eds.). Productive Aging. Baltimore: Johns Hopkins University Press, 2001, s. 175-194. ISBN 978-0801865572.

MOULAERT, Thibauld a Simon BIGGS. International and European policy on work and retirement: Reinventing critical perspectives on active ageing and mature subjectivity. Human Relations, 2012, roč. 66, č. 23, s. 23-43. ISSN 1741-282X.

MPSV. Národni program připravy na stárnutí na období let 2003 až 2007 [online]. Praha: MPSV, (C) 2003 [cit. 20. 5. 2014]. Dostupné z: http://www.mpsv.cz/cs/2869.

MPSV. Národni strategie podporující pozitivni stárnutí pro období let 2013 až 2017 (První draft ke dni 18. 6. 2012) [online]. Praha: MPSV, C 2012 [cit. 23. 5. 2014]. Dostupné z: http://www.mpsv.cz/ files/clanky/13099/Teze_NS.pdf.

MÜLLER, Oldřich. Aktivizační postupy u osob seniorského věku. In KOZÁKOVÁ, Zdeňka a Oldřich MÜLLER (eds.). Aktivizačni př́stupy k osobám seniorského věku. Olomouc: Univerzita Palackého v Olomouci, 2006, s. 36-50. ISBN 80-244-1552-6.

NEILSON, Brett. Anti-ageing cultures, biopolitics and globalisation. Cultural Studies Review, 2006, roč. 12, č. 2, s. 149-164. ISSN 1837-8692.

NEY, Steven. Active Ageing Policy in Europe. Between Path Dependency and Path Departure. Ageing International, 2005, roč. 30, č. 4, s. 325-342. ISSN 1936-606X.

NIMROD, Galit a Hanna ADONI. Leisure-styles and life satisfaction among recent retirees in Israel. Ageing \& Society, 2006, roč. 26, č. 4, s. 607-630. ISSN 0144-686X.

OECD. Maintaining prosperity in an Ageing Society [online]. Paris: (C) OECD, 1996 [cit. 23. 5. 2014]. Dostupné z: http://www.oecd.org/els/public-pensions/2429430.pdf.

PETROVÁ KAFKOVÁ, Marcela. Šedivějící hodnoty? Aktivita jako dominantni způsob stárnutí. Brno: Munipress, 2013. ISBN 978-80-210-6310-5.

RABUŠIC, Ladislav. Senioři a jejich vzdělávání. In RABUŠICOVÁ, Milada a Ladislav RABUŠIC (eds.). Učime se po celý život? O vzděláváni dospělých v České republice. Brno: Masarykova univerzita, 2008, s. 265-287. ISBN 978-80-210-4779-2.

RANZIJN, Rob. Active Ageing - Another Way to Oppress Marginalized and Disadvantaged Elders? Aboriginal Elders as a Case Study. Journal of Health Psychology, 2010, roč. 15, č. 5, s. 716-723. ISSN 1461-7277.

ROWE, John W. a Robert L. KAHN. Successful aging. The Gerontologist, 1997, roč. 37, č. 4, s. 433-440. ISSN 0016-9013.

SÝKOROVÁ, Dana. Autonomie ve stáři. Kapitoly z gerontosociologie. Praha: Sociologické nakladatelství, 2007. ISBN 9788086429625.

TOWNSEND, Peter. The Structured Dependency of the Elderly: A Creation of Social Policy in the Twentieth Century. Ageing \& Society, 1981, roč. 1, č. 1, s. 5-28. ISSN 0144-686X.

TOWNSEND, Jean, Mary GODFREY a Tracy DENBY. Heroines, villains and victims: older people's perception of other. Ageing \& Society, 2006, roč. 26, č. 6, s. 883-900. ISSN 0144-686X.

VIDOVIĆOVÁ, Lucie. To be active or not to be active, that is the question: the preference model of activity in advanced age. Ageing International, 2005, roč. 30, č. 4, s. 343-362. ISSN 1936-606X.

VIDOVIĆOVÁ, Lucie. Institut starobního důchodu jako (de-)motivační faktor na trhu práce. In WINKLER, Jiří (ed.). Nová sociální rizika na českém trhu práce. Problémy a politická agenda. Brno: Barrister \& Principal, Masarykova univerzita, 2008, s. 113-132. ISBN 978-80-87029-49-7. 
WALKER, Alan. A strategy for active ageing. International social security review, 2002, roč. 55, č. 1, s. 121-139. ISSN 1468-246X.

WALKER, Alan. Active Ageing in Employment: Its Meaning and Potential. Asia-Pacific Review, 2006, roč. 13, č. 1, s. 78-93. ISSN 1469-2937.

WALKER, Alan. Active aging is established as the leading global policy strategy in response to population aging. Journal of Aging \& Social Policy, 2008, roč. 21, č. 1, s. 75-93. ISSN 1545-0821.

WHO. Active Aging. A Policy Framework [online]. WHO, (C) 2002 [cit. 25. 5. 2014]. Dostupné z: www. who.int/ageing/publications/active/en/index.html.

\section{Autorka}

Jaroslava Hasmanová Marhánková vystudovala doktorský obor sociologie na Masarykově univerzitě v Brně a nyní působí jako odborná asistentka na Katedře sociologie Filozofické fakulty Západočeské univerzity v Plzni. Ve své práci se prostřednictvím kvalitativních metod soustřed’uje především na otázky stárnutí, genderu a tělesnosti. Její předchozí projekty se mimo jiné zaměřovaly na analýzu politik aktivního stárnutí a životní styly českých seniorů a seniorek. Její aktuální vědecké projekty se věnují zkušenosti a významům prarodičovství v současné české společnosti a konceptu biologického občanství.

Kontakt: jmarhan@kss.zcu.cz 